\title{
Turks and Caicos Islands 2006 coral reef assessment: Large-scale environmental and ecological interactions and their management implications
}

\author{
T.J. Goreau ${ }^{1}$, T. Fisher ${ }^{2}$, F. Perez ${ }^{2}$, K. Lockhart ${ }^{2}$, M. Hibbert ${ }^{2}$ \& A. Lewin ${ }^{3}$ \\ 1. Global Coral Reef Alliance, 37 Pleasant St., Cambridge, MA 02139 USA \\ 2. Department of Environment and Coastal Resources, Turks and Caicos Islands \\ 3. LGL Limited Environmental Research Associates, King City, ONT, Canada \\ Emails for authors: goreau@bestweb.net, fperezm@yahoo.com, tfisherpad@tciway.tc, KJLOCKHART@gov.tc, mar- \\ thabrae1@gmail.com, alewin@asi-group.com
}

Received 10-VII-2007. C Corrected 15-I-2008. $\quad$ Accepted 13-II-2008.

\begin{abstract}
The Turks and Caicos Islands (TCI) has some of the best remaining reef in the Caribbean, but corals are declining as elsewhere in the region. Traditional reef assessment methods cover too little area to accurately characterize complex reef ecosystems, miss large-scale patterns, and high intrinsic spatial variability of reefs inhibits the ability to identify changes or causes. Spatially extensive surveys provide more information, over larger areas, in less time, than intensive ones, revealing large-scale gradients that intensive methods are inherently unable to identify. Extensive surveys were carried out in Providenciales, South Caicos, East Caicos, and Grand Turk. Live coral cover averaged 10-20\%, maximum around 40\%. Dead coral exceeded live coral at all sites. Several past mortality events from disease and high temperature were identified. Dead offshore elkhorn reefs, which protect the shoreline from erosion, are slowly crumbling from boring organisms. Stress from sedimentation was seen down-current from the Cruise Ship Port dredging site. Unexpectedly frequent and severe, but localized, coral disease was seen at many locations, often appearing in intense patches. A special focus of the survey was identifying algae distribution across environmental gradients. 26 ecological and environmental parameters were assessed at 47 coral reef sites across TCI. Transects were parallel and perpendicular to major environmental gradients and spanned their ranges. Correlations between all pairs of ecological and environmental variables were assessed by non-parametric statistics. The matrix of all correlations and significance provided improved insight into interactions between species and their relations to environmental gradients, revealing that many diseases correlate with certain species of algae, which might be reservoirs for pathogens. High algae abundance was seen at almost all sites, with zoned gradients pointing towards nutrient sources. Most dive sites had little algae in shallows, but algae increased dramatically at the drop off edge into deeper water to the thermocline. In many shallow reefs algae zonation indicated land-based nutrient sources from outflow of creeks, marinas, salinas, fish processing plants, hatcheries, or groundwater seepage. Surprisingly high levels of algae were also seen at many remote sites with no land-based nutrient sources. Spatial zonation of algae suggest nutrient inputs from persistent localized upwelling of cold, deep, nutrient-rich water offshore. Green chlorophyll-rich surface water was noted at all sites affected by land-based sources or by offshore upwelling, suggesting widespread high natural nutrient backgrounds. Extensive methods are more cost effective than intensive ones and could be much more widely used for management purposes. The TCI data are being used to develop national water quality management and restoration strategies. Rev. Biol. Trop. 56 (Suppl. 1): 25-49. Epub 2008 May 30.
\end{abstract}

Key words: large-scale coral reef ecological assessment, environmental gradient analysis, non-parametric statistics, coastal zone management, algae zonation, coral community assemblages, diseases, bleaching. 
Turks and Caicos Islands: The Turks and Caicos Islands (TCI) lie at the extreme southeast end of the Bahama Islands chain, but form a separate country (online supplement). The islands are on the edges of two shallow banks (online supplement). Most Turks and Caicos Islanders have always lived from the sea, whether from salt, fisheries, or tourism (Sadler 1997). TCI has developed the strongest coastal zone management in the Caribbean in order to save their marine resources. There is widespread public awareness and support, since the current tourism and financial service economies are vulnerable to the uncontrollable whims of political forces and events outside TCI, and the people could once again be forced to live exclusively from the sea as they did in the past. TCI has some the strongest coral reef protection policies in the world in terms of the proportion of reefs with protected status. Although the Department of Environment and Coastal Resources is small and under-funded, the level of enforcement of environmental laws is among the most effective anywhere: TCI is the only country in the world that is adopting coral reef specific water quality standards, and which ensures that all developments recycle all their wastewater on their own property as plant irrigation to prevent land-based sources of pollution that could damage reefs and fisheries.

Nevertheless, as the reefs continue to decline, there is little information on the current status of the reefs, the changes they are undergoing, or the stresses that cause them, which could be used to guide coastal resource management. Planning for the future will require learning from the past, correctly assessing the causes of current trends, and anticipating the future pro-actively. The purpose of this study was to assess current reef health trends in the light of past observations, and use them as a guide to prepare a strategy that protects and enhances TCI's future fisheries, tourism, and shore protection needs. This study was carried out at the request of the Department of Environment and Coastal Resources, approved by the National Parks Advisory Committee, and funded by the Community Conservation Projects Programme.

Intensive versus extensive assessment: Traditional methods of reef assessment, such as the 1999 AGRRA surveys, count corals (or fish) and estimate total algae abundance along short line transects or in small quadrat frames. We refer to these as "intensive" methods in this paper. Intensive methods give quantitative information, but are laborious, take a lot of time, and cover only a very tiny part of the reef being looked at. Coral reefs are so spatially variable that totally different results can be obtained by placing lines or quadrats just a few meters away. Vast numbers of such measurements must be made before the average measured value converges on the true mean for the reef. Sufficient measurements for statistical accuracy are impractical due to time and funding constraints. Intensive method data give the impression of high precision, but can be unrepresentative of larger areas and so inaccurate at characterizing habitats or associations between variables (specific examples are given in the online supplements). High measurement variability and the extremely small areas measured intrinsically prevent seeing larger scale ecological gradients, yet these larger scales are usually the dominant feature of reefs ecosystems. After such methods were first applied to reefs in Jamaica in the 1960s by T. F. Goreau, they were abandoned as being not worth the time they took for so little information.

A diametrically different philosophy of environmental assessment is to make extensive, large-scale studies of ecological gradients. In the same time it takes to count everything along a single short line or small square, a trained diver can swim over the entire reef and see large-scale spatial patterns that could never be identified by intensive methods, even with many years of measurements. Rather than trying to count everything in a small area, observers look for changes in the abundances of major groups of organisms along long distances perpendicular to and parallel to the major environmental gradients, such as 
distance from shore, depth, wave energy, population centers, nutrient sources, etc. while covering as much ground and different habitats as possible. Special notice is paid to the average abundances of major groups along gradients and the presence of unusual numbers of any organisms at specific sites. These methods are those used in the original 1950s studies by $\mathrm{T}$. F. Goreau first describing the ecological zonation of coral reefs, and in drawing up marine protected area plans to protect reefs in Ocho Rios, Montego Bay, and Negril, in Jamaica, St. John in the Virgin Islands, and Buccoo Reef in Tobago.

Although intensive methods appear to give precise results, they are often inaccurate or inadequate samples of the larger habitat. In contrast, extensive methods are less precise but more accurate on larger scales, and most importantly, they integrate over patchiness of many scales. Each is appropriate for a different class of questions, but extensive methods are much more informative if time and funding is limited because they cover many times larger areas, and are therefore ideally suited to developing countries who must maximize information at minimum cost. Nevertheless, extensive assessment fell out of fashion after 1970 because of the appearance of quantitative accuracy that the intensive methods appear to offer. Users of intensive methodologies regard their surveys as "quantitative" and "scientific", and discount extensive observations as "qualitative" or "merely anecdotal". There is a need to provide an objective and quantitative framework for analyzing extensive observations that allows the unique power of large-scale gradient observations to be expressed in a statistically significant way. The use of non-parametric statistical analysis provides a robust way to do so. Usually parametric statistics are used to test a priori hypotheses, but they can miss patterns in the data that are not specifically tested for. In this paper we are not testing prior hypotheses, we are simply looking how every pair of ecological or environmental variables assessed are related to each other over all the sites. Only then do we form a posteriori hypotheses to explain the linkages between variables found in the data. Thus this method is more consistent with mining data from natural history observations to generate testable hypotheses, than the conventional "hypothesis driven" science, which presumes the expected relationship that is being tested.

Conventional parametric statistical analysis provides a mathematical framework for comparing data as long as it is assumed that each variable measured is described by only two parameters, the mean value and the standard deviation. The assumption is that variability of all values around their mean is described by "normal” bell-shaped Gaussian distribution curves. If real data does not match this assumption, parametric methods can lead to incorrect conclusions. Ecological and environmental data are very rarely "normal". The abundances of many organisms are often highly skewed, so that they are either extremely rare or very abundant. In such cases, mean values and standard deviations are fairly meaningless descriptions, and provide inaccurate impressions of the typical abundance of the population. Non-parametric statistics provide a way to draw strong statistical inferences about the relationships of variable parameters that do not fit "normal" distributions. The value of each variable is ranked qualitatively along a gradient. These can be average bottom cover estimates to the nearest $10 \%$ or qualitative categories, such as "very high", "high”, "medium”, "low", or "very low" as long as they are estimated consistently between sites by the same observers. This allows very rapid and efficient data to be collected over large areas that are impossible with intensive methods, and for statistically sound relationships between them to be derived.

Non-parametric methods have only infrequently been used for extensive assessment of coral reef health. By comparing the Spearman rank order correlation statistics of many ecological and environmental parameters at many sites each pair of variables can be evaluated as to whether they are positively or negatively correlated and the degree of statistical significance 
evaluated. The long-term changes of corals and algae at sites all around Jamaica were assessed with regard to climatic and anthropogenic stresses, showing that areas with the highest algae overgrowth of reefs were near the largest land-based sources of nutrients (Goreau 1992). Goreau and Hayes (1995) examined reefs over a large area of the South Pacific, and found that several parameters were strongly negatively correlated with live coral cover, and that most of these parameters strongly positively correlated with the density of human activities, but none of them correlated with bleaching, which only high temperature did. They concluded that many human activities were damaging corals, but bleaching was related only to high temperature stress, probably caused by global warming.

Previous work: Although TCI has long been regarded one of the Caribbean's top dive destinations, there is surprisingly little material available about the condition of the reefs apart from descriptions of the major dive sites (Gascoine \& Lott 1991, Rosenberg 2001, Harrigan 1992). Assessment of TCI natural resources, including some reef sites, was done in the 1980s by Project Raleigh, and T. Topalian discussed the condition of TCI reefs in 1992, but copies of these reports could not be found for this study. Sullivan et al. (1994) identified coral species in areas of just 15-30 square meters at 5 locations on shelf edge reefs near South Caicos. A description of reefs at sites of Western Grand Turk and near the Bight, Providenciales was included in a DECR report by Goreau (1995). TCI was found to have some of the best reefs in the Caribbean, with live coral cover up to $70 \%$, abundant groupers and big fish, no algae in shallow water except in front of large hotels, and Lobophora algae only on deep walls. Coral reef specific water quality standards were recommended.

Although the Center for Field Studies has operated a teaching and research program in South Caicos for many years, research there has focused on fish behavior, and little has been published on coral reef assessment except for one paper on coral species in reefs near Long Cay, South Caicos (Steiner 1999). G. Gaudian and P. Medley, working with DECR, published a paper on diver damage and diver carrying capacity in Grand Turk (1995) and a book chapter (2000) summarizing the condition of TCI and Bahamas reefs, which described TCI reefs as largely "pristine”. A study of water quality has been done in the Princess Alexandra Park, Providenciales (Perez 2000). A report on reef assessment at major dive sites has been compiled by DECR (Fisher 2004).

The most comprehensive previous reef survey in the Turks and Caicos was carried out in 1999 (Riegl et al. 2003, Hoshino et al. 2003). That study examined 28 locations, most of them close to or similar to those examined in this work, and so providing a useful base for comparison. They found an average live coral cover of only $18 \%$ (range $8-28 \%$ ). Because they regarded TCI reefs as "pristine", they suggested that the reefs must be healthy but that coral cover was low for some unknown natural reason, such as hurricanes. They noted large amounts of standing dead coral in many shallow areas, which is inconsistent with hurricane damage, but did not suggest when or why these corals had died. They noted that algae cover was generally high, and higher on windward than leeward reefs, but offered no explanation of this unexpected pattern.

\section{METHODS}

Field and analytical methodology: Because the purpose of extensive surveys is to cover as much area as possible, detailed counts are not made as in intensive surveys. Instead highly experienced reef ecologists mentally average the abundances they see along the gradient and team members frequently compare their observations and notes right after each dive. If possible the entire transect is digitally filmed or photographed. Coverage of major groups of organisms, such as live coral cover or different types of algae, is estimated to the nearest $10 \%$. While the intensive method gives the appearance of greater precision, in 
fact differences of less than $10 \%$ cover are almost never really significant, and significant differences in abundance can easily be accurately estimated visually to the nearest $10 \%$ by experienced observers. Comparison shows that experienced observers agree on their coverage estimates almost always, and only rarely will two experienced observers disagree by $10 \%$ because they were looking at a somewhat different field of view even when swimming nearby. By discussing their findings at the end of each set of observations, the team has always found it possible to agree on a satisfactory average value that was consistent with the observations of all members of the team. To cross check the coral cover estimates against those measured by standard methods, 100 meter long Reef Check transects were independently run later by Marlon Hibbert and the Reef Check TCI team 14 months later at 5 of the locations reported here.

In this study, 26 different ecological and environmental parameters were assessed at each of 47 different locations throughout the Turks and Caicos. Maps showing all of the locations examined are in the online supplements. All sites were assessed by a team of four: $\mathrm{T}$. Goreau of the Global Coral Reef Alliance, and T. Fisher, F. Perez, and K. Lockhart of the TCI Department of Environment and Coastal Resources. At each site long swims (often several kilometers at a stretch) were taken covering the widest range of conditions at each site, usually as onshore-offshore transects or from land-based sources of nutrients along the shore both in the upcurrent and downcurrent directions from key possible sources of stress. When diving, an effort was made to cover the largest depth range possible. Deep diving and shallow snorkeling sites were picked to represent continuous spatial gradients. Long distances were traveled by being towed behind a boat on a rope, both parallel to the shore and along onshore-offshore gradients to look at larger spatial patterns using the tow surveying method developed in 1969 (Goreau et al. 1972), later popularly re-named 'Manta Tow'. At each location one member of the team took photographs including wide angle photographs to show the general conditions of the site, and close-ups of the most abundant or the most unusual corals, algae, and invertebrate organisms at each site, making a special effort to document coral reef diseases or bleaching. Corals were identified to species and algae generally to genus level. Because algae were dominant at almost all sites, a special focus was on the zonation patterns found in the most abundant algae species. It was not possible to take photographs during tows, as both hands were needed to hang onto the rope, and at a few sites the camera did not work due to battery problems. DECR assessments in the past had focused on major dive sites (Fisher 2004), fisheries stock assessment (largely for conch and lobster, K. Lockhart, personal communication), and at environmental engineering problem response sites (largely pollution or dredging related, F. Perez, personal communication), Since the purpose of this assessment was to look at large scale ecological patterns, this gave the DECR staff a first chance to look at places that they had never dived at before. They found the range of conditions at many sites surprisingly different from those they had experienced previously. Following the dive assessments, meetings were held with the oldest divers on Providenciales and Grand Turk to discuss their observations on historical changes.

After each dive, snorkel, or tow, the team drafted group notes comparing their observations. Notes indicated the typical coverage of the site, noted any spatial gradients, and any unusual organisms seen. At the end of the field studies, the notes and the photographs were used by the team to discuss each site, and to rank the chosen ecological and environmental parameters in a consistent way at all sites. The field notes and photographs are available as on-line appendices. The parameters chosen in this study were all readily visually estimated. Quantitatively measured parameters could also be included in this analytical scheme, but the team had no quantitative measuring instruments, except a boat mounted GPS for part of it. Therefore the parameters selected included 
the major groups of organisms and bottom types, environmental parameters such as depth, distance from shore, wave energy and exposure, turbidity, water color, and distance from land-based sources of nutrients such as cess pits, septic tanks, other waste water treatment systems, garbage dumps, channels from harbors or lagoons, and the abundance of key indicator algae species.

While there are several Caribbean corals that are characteristic of very shallow or deep sites, most Caribbean corals are found in a wide range of depths, and the major zonation was historically caused by the former near complete domination of Elkhorn (Acropora palmata) and Staghorn (Acropora cervicornis) in the shallow wave breaking zone, with other coral species dominating in the shallow lagoon behind or on the deeper reef in front (Goreau 1956, 1959, Goreau and Goreau 1973). This zonation was very common in TCI in the 1970s but is now only very weakly present due to the very small amount of Acropora remaining. Since algae dominated most reefs in 2006, and since algae species are very sharply zoned along ecological gradients (Goreau 1992), algae species were used as the primary indicators of zonation rather than coral species. Indicator algae species that were picked for ranking were macrophyte (larger algae not needing a microscope for identification) species that were very abundant at several places, and that could be quickly ranked at all sites.

All parameters were ranked on a scale from 1 to 5 . The parameters chosen for comparative assessment at all sites were:

1. Live coral cover. The best indicator of reef health

2. Bare cover. Clean hard rock and dead coral not covered by algae, suitable for new coral settlement

3. Padina. Algae typical of shallow low nutrient areas

4. Lobophora. Algae typical of deeper and of nutrient rich areas

5. Stypopodium. Algae typical of moderately high wave energy
6. Sargassum. Algae often dominant in high wave energy areas

7. Turbinaria. Algae often found in high wave energy areas

8. Dictyota. Very common algae that spreads at low to moderate nutrients

9. Crustose coralline red calcareous algae. Algae typical of very low nutrients

10. Branching red calcareous algae. Algae typical of low to moderate nutrients

11. Laurencia. Algae typical of low to moderate nutrients

12. Microdictyon. Algae typical of high nutrients

13. Cladophoropsis. Algae typical of high nutrients

14. Calcareous green calcareous algae. Algae typical of low to moderate nutrients, major beach sand source

15. Cyanobacteria. Algae typical of very high nutrients, especially phosphorus

16. Bleaching. Coral alive but pale and severely stressed, usually by high temperature

17. White Plague. The disease that spreads fastest, affects most corals

18. Black Band. Disease affecting massive corals

19. Gorgonian disease. Disease affecting sea fans and sea whips

20. Exposure. Degree of wave exposure, depends on geographic orientation of shoreline

21. Depth

22. Development. Amount of population and infrastructure on nearest shoreline

23. Turbidity. Low visibility due to suspended sediments from dredging or wave action

24. Green water. Low visibility due to high levels of phytoplankton

25. Point source. Proximity to major sources of nutrients from septic tanks, canals draining salinas or creeks, marina channels, or fish processing plants

26. Seepage. Ground water flow from inland salinas, lagoons, cesspits, septic tanks, and garbage dumps.

Other parameters could easily be added to the list or subtracted from it. 


\section{RESULTS}

The non-parametric statistical analysis of the data, showing the Spearman correlation coefficients between each pair of variables from the rank order listings at all sites, and whether these variables are positively or negatively correlated with each other, as well as the degree of statistical significance, is shown in Table 1. Detailed spreadsheets of the field data, the field notes, the field photographs, and the 1995 Goreau report are available at: http:// globalcoral.org/Turks\%20and\%20Caicos\%20 Islands\%20Coral\%20Reef\%20Health\%20 Assessment.htm

An overview of the general field observations with regard to coral abundance, coral health, algae abundance and distribution, water quality with regard to water color, sediment, and pollution, and shore erosion is provided below. In addition to the underwater observations, observations of the reefs were made from the air. These are discussed below in a separate section. This section is followed by an analysis of the results of the patterns that emerged from the data analysis, many of which were not previously noticed.

Comparison of visual estimates of coral cover with line transects: The Reef Check TCI transects were run at 5 of the sites assessed in this study, 14 months later. Each transect is 100 meters long, and took around 2 hours with a team of 5-6 people. The visual assessments reported here would typically cover a kilometer or more in the same time interval. The Reef Check protocol assesses parameters that were not assessed in the visual survey, and our protocol included many more parameters not in the Reef Check protocol. Therefore we compare only the live coral cover estimates. It must be remembered that because the Reef Check assessment covered circa one tenth the area of the extensive surveys, there is a very good chance that the transect data represents only a single sub-habitat and not the entire region assessed by the extensive surveys. The Reef Check method is more precise, but the extensive method is a more accurate description of the larger habitat. Three of the five Reef Check transect values were within the $10 \%$ limits of precision of the visual estimates, and two were lower (below). These differences could reflect that the corals had further deteriorated in the 12 months between surveys, as they were locations with extensive coral disease outbreaks at the time of the first observations. Alternatively, the Reef Check surveys, covering a much smaller area than the visual estimates, could have been placed in microhabitat areas that were not representative of the larger area surveyed in the visual survey. Concurrent surveys will be needed in order to resolve this and fully compare the two methods.

Coral cover: Live coral cover was surprisingly low at all sites. All sites had more dead coral than live coral, and in many the live coral was extremely low. Most reef sites had live coral cover between 10 and 20\%. The highest values for live coral cover seen in TCI reefs were around $40 \%$ at the healthiest shelf edge wall and slope reefs (the best healthy coral reefs should have approaching 100\% live

TABLE 1

Comparison of live coral covers visually estimated at 5 sites in June 2006 compared with Reef Check transects at the same locations measured in August 2007

$\begin{array}{lcc}\text { Dive Sites } & \text { Visual estimates June } 2006 \text { Hard coral \% } & \text { Reef Check Aug 2007 Hard Coral \% } \\ \text { Pinnacles } & 20-30 & 31.88 \\ \text { Aquarium } & 10-20 & 13.75 \\ \text { Coral Gardens } & 30-40 & 6.25 \\ \text { Smith's Reef } & 10-20 & 6.25 \\ \text { Arches } & 15-25 & 8.75\end{array}$


coral cover). A large fraction of the dead coral appeared to have died within the last 5-10 years based on the preservation of the dead coral surface and the height difference between live and dead portions of the partially dead colonies. It is thought likely that much of this partial mortality was due to bleaching and coral disease. Dives in many of the best locations on Grand Turk in 1995 had found live coral cover of up to $70 \%$ (Goreau 1995), implying that nearly half the corals had died at the best sites in 11 years. In 1995 a coral mortality event about 5 years old was clearly visible, probably due to the severe bleaching events in 1990 and 1987, which had been the hottest years in TCI up till that time. Satellite derived monthly average sea surface temperatures for TCI from 1982 through 2003 (Fig. 1, Hayes \& Goreau in press), shows that record high temperatures were reached in 1998, and almost every year since then has equaled or exceeded the temperatures that caused bleaching in 1987 and 2000. The dead portions of large corals seen in this study, which appeared to have died 5-10 years previously based on their height differences, are most likely to have died after bleaching in 1998. In some shallow locations, for example southeast of Grand Turk, almost all large head corals were dead on top but alive on the sides, a characteristic typical of partial bleaching mortality. An opposing pattern is often caused by White Band Disease, which usually proceeds from the bottom up.

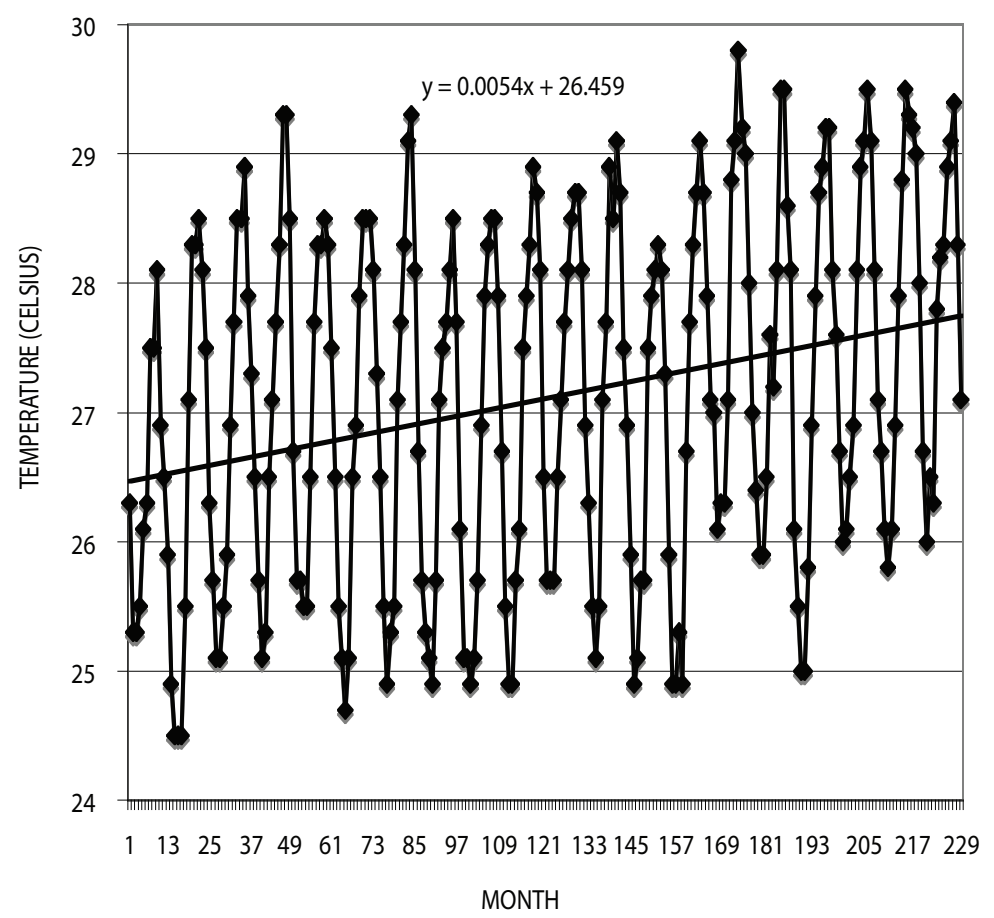

Fig. 1. Monthly average TCI sea surface temperatures (in degrees C), 1984-2003 (from Hayes \& Goreau 2008). The number on the horizontal axis is the number of months starting in January 1984. There is a clear upward trend in maximum, minimum, and mean temperatures, caused by global warming. The warmest year was 1998, but almost all years since 1998 have been very warm, making bleaching a nearly annual event. 2004 and 2005, not shown, continued this pattern, with hotter conditions and more bleaching in 2005. Years of known bleaching correspond to monthly average temperatures causing bleaching are seen to be $29.4^{\circ} \mathrm{C}$ and above. 
Only current bleaching, not likely past bleaching mortality, was tabulated. Bleaching was distinguished from disease, which can often be confused with it, by the presence of live, but pale, tissue over the skeleton, and the characteristic species-specific gradients of color seen across bleached corals. The bleaching seen was residual slow recovery from bleaching in 2005 (online supplement). This recovery appeared to be much slower in some sites than others, but without knowing the intensity of bleaching at its peak the previous year at each site, it is hard to be sure. The high, but patchy, older coral mortality after the 1998 bleaching event observed in this study was apparently not recognized in the 1999 survey by Riegl et al. A healthy patch of staghorn coral that had been found at the southern tip of Grand Turk in 1995 was completely gone 11 years later. It is clear that there has been a progressive decline in live coral cover over the past $15-20$ years at all sites. A large amount of even older coral mortality was clearly visible at many sites. Huge dead standing elkhorn coral reefs were seen at many locations in northwestern Providenciales, northern Grand Turk, and the islands southeast of Grand Turk. Some locations had a few younger live elkhorn corals, but with very little overall recovery compared to the amount of old dead elkhorn at the same sites. Large amounts of dead staghorn rubble were found at some locations on northern Grand Turk. Staghorn and elkhorn coral were once very abundant, but are now rare everywhere. This has serious environmental implications because the open branching of these corals provides the best habitat and hiding places for most reef fish, the best snorkeling areas, and because they grow in shallow water and are the best corals at breaking waves, for absorbing wave energy, and reducing beach erosion at the shoreline. Discussions with the earliest divers, who founded the first dive operations in Grand Turk in the 1980s, revealed that these areas were already dead when they had started diving. The first dive operations in Providenciales were set up in the 1970s, but the divers concentrated on fishing and did not pay attention to corals. It is quite certain that these huge coral formations died during the Caribbean-wide epidemic of White Band Disease that killed almost all Elkhorn and Staghorn throughout the Caribbean around 1979 (Gladfelter 1982). Unfortunately there are no known older observations and photographs that would help establish the date, although interviews with the oldest fishermen should provide this information. The low coral cover was surprising, because TCI reefs are among the best in the Caribbean in terms of coral cover and because they have much lower sources of land-based sources of pollution than almost any other islands, due to the low population and semi-arid climate, which causes very low runoff. TCI reefs are widely regarded as "pristine" but it is clear that the corals are dying much faster than new coral colonies can colonize the area, as seen by the large amounts of bare substrate at some locations that is ideal for coral settlement. Recruitment of new coral larvae from planktonic sources is probably very low because there are few areas with good sources of coral larvae upcurrent from TCI due to its exposed open Atlantic location. The major sources of stress to the reefs, while linked to development, dredging, and land based sources of pollution at several shallow reef sites, appears to be largely due to global warming and new diseases, and oceanographic factors, none of which can be controlled by local measures.

Coral diseases: Epidemic levels of coral diseases were found at many locations. The most abundant was White Plague (online supplement), which was seen at almost all sites. At most locations only isolated cases were found, but at many locations patches of reef in which a large portion of corals had White Plague, separated by intervening areas with few or no cases, were found. In some of these patches most of the coral species were affected. While massive corals were generally most affected, most coral species were found to have some colonies being killed by White Plague, including massive, branching, and plate corals. We counted only cases in which White Plague 
was actively killing corals at the time of the observation, indicated by large areas of fresh white skeleton that had only lost its tissue in the last few days, before algae could overgrow it. But we did also see many corals with older dead portions that looked as though they had died from white plague previously, as noted from the typical bottom-up mortality pattern, but that the disease had stopped before killing the entire colony (often with totally dead corals nearby). White Plague, while it will completely kill smaller corals, often stops before it completely kills larger corals, leaving dead patches of characteristic shape, usually on the sides. White Plague may be seasonal if, as seen elsewhere, White Plague spreads most rapidly in the warmer months and stops when water gets cooler. Without catching diseases in the active stage, it is very difficult to assign older mortality, so we did not include older partial mortality in our White Plague estimates. White Plague was so widespread, and so locally abundant at many places, that it is likely to be the major killer of TCI corals at this time. Black Band disease (online supplement) was also found to be locally very abundant, but at a smaller number of places than White Plague. This disease kills corals at a few centimeters a month (while White Plague does so at several centimeters a day) and affects a smaller number of species, primarily the large head corals. Most sites with a lot of Black Band were very remote from human pollution sources, in fact it was almost never seen at places where land-based pollution is a possible stress factor. However in many cases the white recently dead area behind the black band was very broad, up to ten times or more wider than normal, making it appear as if it were combined with White Plague. The same was true of White Band Disease, which was generally fairly uncommon because of the rarity of the affected elkhorn and staghorn corals. In contrast to White Plague and Black Band, Yellow Band, Dark Spot, White Pox, and White Spot Diseases were present but far less common, usually isolated, and rarely aggregated into intense patches. Gorgonian Disease (online supplement) was seen at high levels in sea fans and sea whips, but only in a small number of places, and most locations showed no signs of either. In some places large amounts of dead sea whip remains were found piled up on the bottom. Coralline Algae White Line Disease (Goreau et al. 1998) was seen in isolated places wherever encrusting coralline red algae were abundant, and one case of possible Coralline Lethal Orange Disease was seen. Given that these observations were made in June, before the water warmed up to the usual seasonal maximum, it is possible that the disease outbreaks noted were in their early stages, and so it will be very important to continue observations through the following cool and warm seasons.

Algae: Several very distinctly different algae communities were found at different sites, some associated with land based sources of nutrients, others with offshore exposure, and others lying in between (see field notes in on-line appendices). In some cases particular species of algae were found to be dominant at a single site, and rarely or never found at other sites. These very locally abundant but uncommonly found species were noted, but were not used as indicators because the number of sites where they were found was too rare to be statistically significant. Algae were the dominant cover on hard bottom at almost all sites, but the species dominance varied greatly from site to site (details in field notes and data logs posted at www.globalcoral.org). High presence of algae indicates the nutrient supply feeding them promotes faster growth than algae eating fish and other organisms can consume. This finding was extremely surprising because landbased nutrient sources in TCI are relatively small and localized, and the fish populations are some of the healthiest in the Caribbean. Algae are the best indicators of environmental conditions, with different species being most abundant under different conditions of nutrients, light, and wave energy. While a few algae species were very broadly distributed, such as Dictyota and the calcareous sandproducing green Halimeda, most algae were 
clearly zoned, being most abundant in certain habitats and rare in others. Algae covered most of the hard rock surface and dead corals almost everywhere, preventing the possibility of new coral settlement. Clean white limestone rock surfaces that had been noted previously in shallow Grand Turk reef sites (Goreau 1995) were largely covered with macro-algae or micro-algae turf at most locations in this survey. The exceptional locations with very low algae cover were found at sites south and east of South Caicos, certain sites on Providenciales and southwest Grand Turk, and patches on shallow fore reefs with very high wave energy exposure. There were distinct regions where both shallow and deep reefs had high (or both had low) algae. Algae indicative of very high nutrients were focused wherever land-based point sources of pollution and groundwater seepage enter the sea. The factors affecting the distribution of the different major algae groups are discussed in further sections, especially the statistical data analysis, and in the appendix of detailed site descriptions. One striking feature in the algae, as previously noted (Goreau 1995) was the strong increase in Lobophora variegata and calcareous green algae with depth going down the drop off. This suggests that the nutrients at these sites are coming from upwelling and mixing of deep cold North Atlantic waters from below the thermocline, which are much higher in nutrients than warm shallow water. At two locations off northwest and southwest Grand Turk we dived down to the thermocline. At the northern location the thermocline was shallower, 90 feet, and at the southern location it was deeper, 120 feet. These depths corresponded to the maximum abundance of Lobophora with depth at each site. Upwelling of deep nutrients must therefore be considered an important source of nutrients for deep and offshore reefs, even those remote from landbased sources of nutrients.

Pollution: Since there is very little industry or agriculture in TCI, the major source of pollution is sewage. Unless sewage is treated to tertiary level to remove the nitrogen and phosphorus, these elements, which are the major limiting nutrients for algae, will remain in residual waters after treatment. If these waters are not recycled on land, the nutrients in them will be released to the ocean by direct discharge, or build up in the water table and underground seepage into the sea. Almost all major developments in TCI have secondary sewage plants with complete wastewater recycling on their own property and low discharges to the coastal zone. This is accomplished via using wastewater irrigation of trees, shrubs, and lawns on site, and TCI is the only place we know in the world to mandate this from all developers. But most older homes have cesspits or septic tanks. Algae indicative of very high nutrients were found near all major sources of nutrient pollution previously known to DECR, such as the entrance to enclosed harbors and marinas, the outflow channels of the most polluted salinas, conch and lobster processing plants, the conch farm, areas of septic and garbage disposal, as well as in previously unidentified areas where nutrient-rich groundwater soaks into the sea from salinas and septic seepage. Algae levels were much higher in 2006 at all the shallow sites that had previously been looked at in 1995, indicating an increase in land-based sources of nutrients following increasing population and tourism. However no algae buildups were found at the outlets of bodies of water, such as North Creek, which receives almost no sewage nutrients. These patterns suggest strongly that nutrient sources, not lack of algae-eating organisms, are the cause of the high nutrients in many shallow coastal waters near populated areas. However large amounts of algae were also found at many locations remote from all obvious land-based sources of nutrients, including very exposed sites where there is little fishing. The significance of those sites is discussed in the next section.

Green water: Water with a strong green color and reduced visibility, due to high levels of phytoplankton algae, was very noticeable in many places, both while diving and from the 
boat while traveling between sites. Some areas of green water were those previously known to be impacted by land-based sources of nutrients, such as the marinas on Providenciales, the Conch Farm, areas near the fish processing plants on South Caicos, and the areas of salina outflow on Grand Turk. However green water conditions were also encountered at many sites remote from any possible land based sources of pollution, for example east of the uninhabited island of East Caicos, North West Point on Providenciales, the North East Barrier Reef of Grand Turk, and the uninhabited islands southeast of Grand Turk. In all areas where the water was distinctly green, macro-algae or micro-algae turf densely covered the bottom. The areas to the south of South Caicos, and areas of Providenciales and Grand Turk, which had distinctly blue water, also had the least algae cover. This strongly suggests that many parts of TCI reefs are strongly affected by upwelling of deep nutrient rich waters, so that the algae problem affects much larger areas than those affected by land-based sources of nutrients alone. While ephemeral green water can be caused by episodic upwelling events, the distinct spatial patterning of shallow and deep reefs into blue water areas with high coral cover (where all the tourist dive sites are located) interspersed with areas with green water, low coral, and high algae, suggests that the upwelling patterns are chronic and persistent, and that systematic long term algae and coral abundance patterns may be linked to upwelling at distinct sites. These preferred upwelling sites probably result from to ocean circulation patterns influenced by submarine topography, but there is little direct oceanographic data to test this hypothesis. Almost the entire Northern Barrier Reef of Grand Turk and most of the Northern Barrier Reef of Providenciales consists of limestone hardground rock overgrown by algae, with very little coral. The limestone surface is an old erosional limestone surface, sculpted into spurs and grooves by erosion. Real spur and groove topography is purely of erosional origin, the spurs are smoothed by erosion and the grooves are full of rounded boulders, not sand, and there is little or no live coral on their sides. Unfortunately many coral reef researchers mistakenly continue to misuse the term "spur and groove" to refer to constructional reef, which has a completely different origin, with channels covered with live corals and a sand bottom. These should be properly called "buttress and canyon" topography (Goreau 1956). These shallow spur and groove areas are not dead reef that has been recently overgrown by algae, instead they are made of older limestone, subject to very high wave stress, and have never had constructional coral reefs growing on them. Their widespread distribution suggests that the green water and algae dominated conditions at these sites has a long and continuous historic past, and is not a recent phenomenon. This has several important management implications. First, the dive sites, which are located in the clearest waters, were not selected simply because they are just the closest good dive sites among many pristine locations, but because the earliest dive operators did not find good dive sites elsewhere. As a result, there is little additional room to expand diving to if the best areas are damaged. This makes their protection from diver and anchor damage even more important. Second, it also indicates that many parts of TCI shallow water habitats have chronic excess nutrients of natural upwelling origin, and therefore that is even more crucial to prevent land-based sources of nutrients from contaminating the nearshore areas because there is already a high background of nutrients from offshore sources. The importance of upwelling was unexpected, and had not previously been identified apart from a description of sporadic upwelling in Goreau (1995). Gaudian and Medley (2000) had concluded that upwelling did not affect the TCI or the Bahamas.

Turbidity: High turbidity from suspended sediments was noted in front of beaches exposed to waves, such as northern Providenciales, and in the reefs around the areas dredged for the cruise ship terminal on Grand Turk. A large area of reef down current from the terminal 
appeared to have suffered greatly from excessive sedimentation caused by dredging, with many corals dead on their tops and others still alive but covered with fine sediments and in poor condition. Reefs upcurrent were far less affected. This indicates that mitigation is needed for the damages to reef habitat caused by the dredging for the port. The area affected had been one of the highest live coral cover sites seen anywhere in TCI, and constitutes the best shallow water coral cover and potential shallow diving sites on Grand Turk. A rescue operation to remove the living, but damaged corals, and transplant them to a location nearby, but upcurrent of the sediment source from dredging and prop wash, would allow them to recover and form a new reef where there is now none, as well as protect Governor's Beach from eroding.

Shore erosion: High rates of shore erosion, indicated by an erosion scarp or cliff on the beach, trees falling into the sea, and defensive building of walls in front of buildings, was seen at the northeastern end of Providenciales, and at the northern end of Governor's Beach, north of the Grand Turk cruise ship terminal. Given the extremely low lying nature of most of the TCI, and the fact that global sea level rise, currently 3 millimeters per year, will rise sharply as global warming causes increased melting of glaciers and ice caps and causes shallow ocean water to expand, while it increases hurricane strength and frequency, these areas of erosion may be a harbinger of much more erosion to come, and require a pro-active general strategy to protect the shorelines quite apart from their economic value as tourist beaches.

\section{Aerial observations:}

Please see maps in online supplements for locations of islands discussed.

1. There are a very large number of small patch reefs on the east Grand Turk Shelf that there was no time to look at during the field survey, although they look similar to those examined on the islands south east of Grand Turk, which forms the southern end of this zone, and those examined at the very northern barrier reef end. The water was distinctly greenish all over the shelf, and all the patch reefs are very dark brown, probably because of high brown algae cover, such as Lobophora, Sargassum, and Turbinaria. Several things can look dark brown from the air, including either healthy corals or masses of brown algae, and need to be confirmed by underwater observations. However it is pretty sure that these areas are largely algae lawns from our observations of similar appearing habitat in the islands southeast of Grand Turk, and the northern barrier reef, the two ends of the shelf. Were this live coral, the coral that would have dominated this habitat, elkhorn, is distinctively golden yellow brown, not dark brown. It therefore seems that all the entire east and north shelves of GT is algae covered, as Mitch Rollins, owner of one of the oldest dive shops on Grand Turk, had said when asked why there was no diving on those sides (Goreau 1995).

2. The water on the shelf off southeastern East Caicos, and the east side of South Caicos down to the point where the coast changes from north-south to east-west, was greenish, all the reefs were dark brown with algae, and the water was opaque enough that the drop off was not clearly visible from the air. It seems that these areas, which South Caicos fishermen said always have green water, have chronic upwelling conditions. On the other side of the point, the south facing shore of South Caicos, where we found the lowest algae, the water was clear and blue, and the drop off was clearly visible from the air. The aerial observations are completely consistent with field observations. The differences between green algae dominated sites and blue coral sites seems to be chronic, not due to some very recent upwelling episode that we had fortuitously ran into at the time.

3. The waters on the Caicos Bank are mostly very clear, almost all clean white sand, 
with almost total lack of well developed sea grasses except near inhabited islands with nutrients from salina seepage, sewage, and conch and lobster processing plants dumping guts in the water. This distribution implies that they are nutrient limited (except perhaps near the mangrove areas of North and Middle Caicos). There seems to be a very clear gradient in seagrass lushness away from land implying the nutrients are land-derived. Seagrasses need much higher nutrients than coral reefs, and turn eutrophic (being overgrown by weedy algae) at nutrient levels much higher than those that kill coral habitats by algae overgrowth. Lapointe et al. (1994) have published hyper-eutrophication limits for seagrasses in Florida, at which they are smothered by weedy algae, 25 micromolar Dissolved Inorganic Nitrogen and 0.4 micromolar Total Phosphorus, or 25 and 40 times higher than the value at which coral reefs become algae dominated.

4. The waters of Chalk Sound and the south side of Providenciales were amazingly clear and lacking in seagrasses despite high light levels. The channels had very clear and blue water. This implies very low nutrient loading. Because these very shallow waters are extremely vulnerable to massive algae overgrowth from nutrients, it is important to prevent any land-based sources to this area from underground seepage of septic tanks or fish processing wastes.

5. There are morphologically separate shallow reef frameworks on the wave-breaking barrier north of the Bight, north of Grace Bay, and from Leeward Going Through Sound northeast to Water Cay. The waters off north Providenciales had greenish tints, and the drop off was not clearly visible, both north of the Bight, and in the area from Leeward Cut eastward, areas where we found high algae cover of shallow fore reefs. In these areas the shallow reef crest, where there is heavy breaking wave impacts and there is exposed old limestone hardground, appears pale from the air, due to waves scouring algae off the limestone hardground, but the outer shallow reef slope immediately in front of it is dark brown with algae. In sharp contrast to those sites, the reef in front of Grace Bay, lying right between them, where we found much less algae in both deep and shallow reefs, is pale in the whole front slope reef area, markedly lacking the dark brown algae covered areas on the shallow fore reefs on either side. The water was clearly bluer, and the drop off was visible from the air. This appears therefore to reflect a chronic and consistent difference in upwelling over a short distance. The plane also went towards North Caicos before turning. The same transition to clearer water and paler fore reef takes place again further east towards North Caicos. These sharp changes over short distances are surprising, but they seem meaningful.

6. It will be important to extend these observations throughout TCI. Aerial surveys and filming from a low flying air craft over the reefs all around Provo, Grand Turk, South Caicos, West Caicos, North Caicos, Middle Caicos, East Caicos, Salt Cay, and outlying islands to document patterns of water clarity, color, and the color of the hardground fore-reef frameworks, if done on a very clear calm day, will be very valuable in identifying and mapping all areas subjected to localized upwelling. It appears that there is a very complex pattern of upwelling, probably linked to bottom orientation and topography, and we hypothesize that the thermocline depth varies considerably, making an oceanographic study of upwelling, or at least of surface and deep temperature profiles, and mapping of nutrients, very desirable.

Nonparametric statistical data analysis: overview: The 26 variables whose values were tabulated at all 47 sites were compared statistically, pair by pair at all sites, to contrast their rank order correlations, and the sign and 
significance of the Pearson non-parametric rank order correlation coefficients were tabulated (Table 1). A positive correlation coefficient means that when one variable increases, so does the other. A negative correlation coefficient means that when one variable increases the other decreases. Statistically significant correlations (S) have more than a 95\% probability of being true, and less than a 5\% probability of happening by chance. Strongly significant correlations (SS) have more than a 99\% probability of being true and less than a 1\% probability of happening by chance. Very strongly significant correlations (VSS) have more than a $99.9 \%$ probability of being true and less than $0.1 \%$ likelihood of happening by chance.

When the entire matrix of 325 interactions between all pairs of ecological and environmentally variables assessed in this study is examined, $19.69 \%$ of the relationships between variables are statistically significant, and $80.31 \%$ are not. 64 interactions were statistically significant (41 of them positive (12.6\%) and 23 of them negative (7.1\%)). The breakdown by level of significance and sign is given in Tables 2, 3.

Every single variable examined had at least one significant correlation with another variable, and some had many. The distributions of variables that have more significant interactions with other factors contain more information about the overall status of the reef than other less closely linked parameters. Because most of the interactions between variables were not significant, it is easier to see the structure of interactions between variables by presenting them in two diagrams (Fig. 2 and 3), the first showing the positive interactions, and the second showing the negative interactions. Significant interactions between variables are indicated by thin lines, strongly significant interactions by medium lines, and very strongly significant interactions by thick lines. In both of these diagrams the number of significant interactions of each variable is clear, and groups of variables that are strongly interacting can be easily identified. These diagrams provide rich and often unexpected insight into how the ecological parameters are related to each other, and how they are related to environmental variables, most of which could not easily be identified otherwise. In addition these linkages provide the basis for a simple dynamic simulation model that can be used to explore the results of changing any one variable on the others. These linkages are discussed in detail in the online supplements, along with plausible mechanisms to explain them. In some cases alterative explanations could also be proposed, but these seemed the most likely ones.

\section{DISCUSSION}

Coral disease patterns: Many long known correlations between variables, such as

\section{POSITIVE CORRELATIONS}

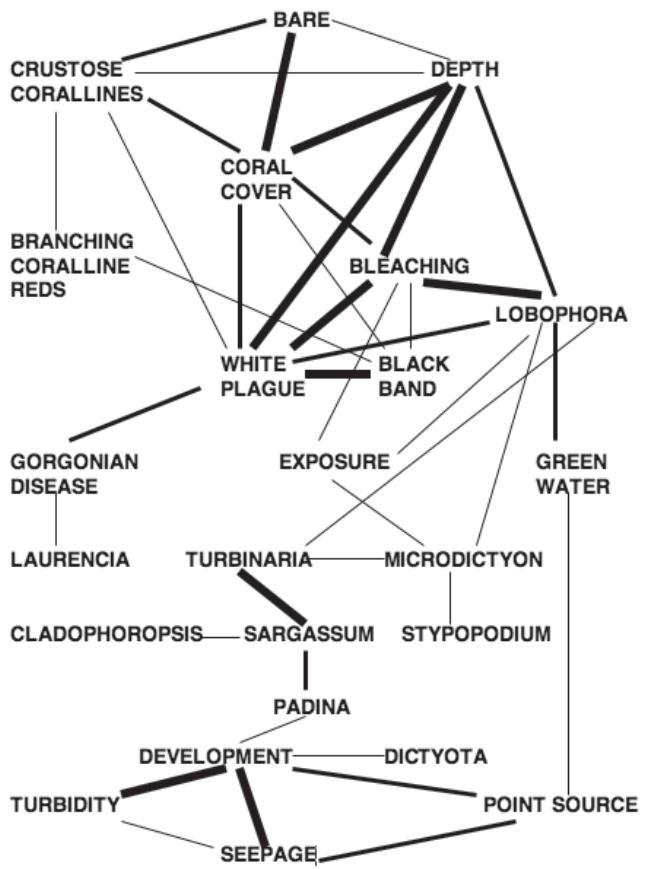

Fig. 2. Network of statistically significant positive correlations between ecological and environmental variables emerging from the non-parametric data analysis. Thin lines indicate correlations significant at the $95 \%$ confidence level $(\mathrm{P}<0.05)$, medium lines indicate significance at the 99\% level $(\mathrm{P}<0.01)$, and thick lines at the $99.9 \%$ level $(\mathrm{P}<0.001)$. 


\section{NEGATIVE CORRELATIONS}

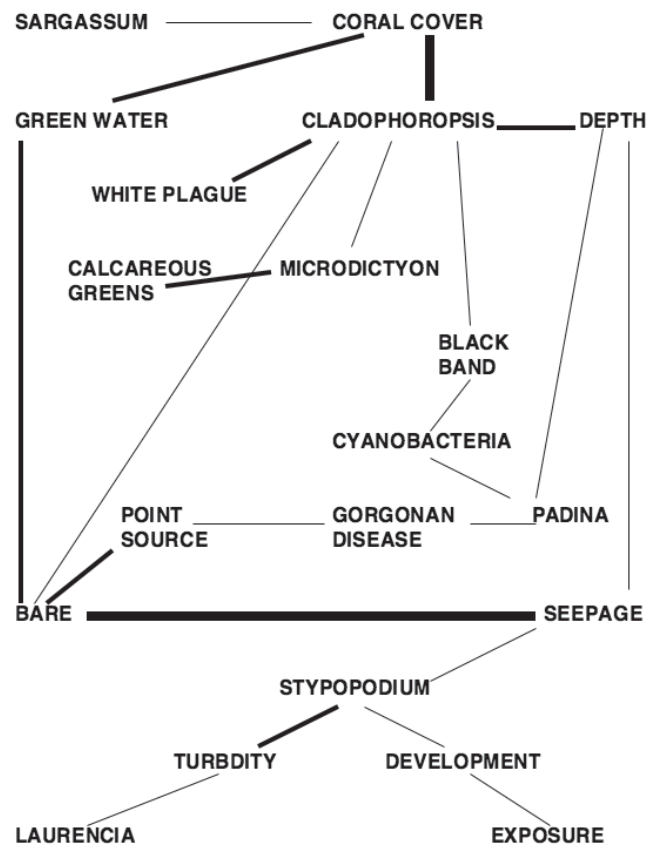

Fig. 3. Network of statistically significant negative correlations between ecological and environmental variables emerging from the non-parametric data analysis. Thin lines indicate correlations significant at the $95 \%$ confidence level $(\mathrm{P}<0.05)$, medium lines indicate significance at the 99\% level $(\mathrm{P}<0.01)$, and thick lines at the $99.9 \%$ level $(\mathrm{P}<0.001)$.

those related to intensity of land development nearby, are shown in the network of significant associations revealed by this data. Of special interest is the large numbers of statistically significant linkages between coral diseases and algae. These were wholly unexpected, since they could probably not been detected with intensive reef assessment methods, were not really noted in the field observations (previous sections), and emerged purely from the large scale data correlations at all sites. Previous studies had suggested possible links between certain diseases and certain algae, based on small-scale quadrat observations in Curacao (Nugues et al. 2004), and from experimental laboratory manipulations (Smith et al. 2006).
But the specific correlations our study found were different from those had been proposed earlier. These TCI results suggest a specific range of algae to be tested as potential hosts for each disease. It shows little link between disease and development or pollution, which have often been pointed to as possible causes or promoters of disease. It also shows that several of these diseases correlate with each other, suggesting they are affected by a common stress or group of pathogens. It is clear that much would be learned about conditions promoting spread these diseases if both large and small-scale studies were combined with microbiology, and much further research along these lines is needed to test the hypotheses generated by the data analysis of this paper. Sewage has been proposed to promote coral disease (Kaczmarsky et al. 2005), and this effect could be due to bacteria (Klaus et al. 2007), nutrients (Bruno et al. 2003), or organic carbon, all of which are high in sewage. Nutrients should directly affect autotrophs rather than heterotrophs or parasites. When nutrients and organic carbon are varied independently, organic carbon is found to increase disease spread, probably by providing food to bacteria, but nutrients alone are found to have no significant effect (Kuntz et al. 2005). While it seems intuitively obvious that human stresses should increase coral susceptibility to disease, the lack of strong linkages between coral diseases and indicators of human impact found in this study imply that the random distribution of pathogens in the water, not the "health" of the corals with regard to anthropogenic stress, is the dominant factor in explaining the patchy distribution of disease in both sites near and far from human impacts.

Algae distributions: Little work has been done on reef algae community associations, but our results confirm that algae zonation is very well developed (Goreau 1992), and that there are characteristic species assemblages in many well characterized habitats, so that algae zonation potentially reveals much more information about ecological patterns than coral distributions. Algae ecology has been traditionally 
TABLE 2

Matrix of Spearman rank order correlation coefficients between all pairs of variables. The triangular lower left half of the matrix gives the numerical value of the correlation coefficient. Numbers unmarked are not statistically significant $(P>0.05)$, numbers marked by * are statistically significant at the $P<0.05$ level, numbers marked by ** are strongly statistically significant at the $P<0.01$ level, and numbers marked by $* * *$ are very strongly statistically significant at the $P<0.001$ level. The triangular upper right half of the matrix gives the sign of the correlation. Abbreviations given in text.

\begin{tabular}{|c|c|c|c|c|c|c|c|c|c|}
\hline & $\begin{array}{l}\text { Coral } \\
\text { Cover }\end{array}$ & $\begin{array}{l}\text { Bare } \\
\text { Cover }\end{array}$ & Padina & Lobophora & Stypopodium & Sargassum & Turbinaria & Dicttyota & Crustone \\
\hline Coral Cover & 1.00 & + & - & - & + & - & - & + & + \\
\hline Bare Cover & $* * * 0.52$ & 1.00 & - & - & + & - & - & - & + \\
\hline Padina & 0.27 & 0.04 & 1.00 & - & + & + & + & + & - \\
\hline Lobophora & 0.02 & 0.12 & 0.07 & 1.00 & + & + & + & - & - \\
\hline Stypopodium & 0.07 & 0.18 & 0.13 & 0.05 & 1.00 & + & - & - & + \\
\hline Sargassum & $* 0.34$ & 0.13 & $* * 0.40$ & 0.05 & 0.20 & 1.00 & + & + & - \\
\hline Turbinaria & 0.27 & 0.09 & 0.08 & $* 0.32$ & 0.01 & $* * * 0.55$ & 1.00 & + & - \\
\hline Dictyota & 0.08 & 0.02 & 0.08 & 0.03 & 0.06 & 0.21 & 0.19 & 1.00 & + \\
\hline Crustose Reds & $* * 0.44$ & **0.39 & 0.05 & 0.06 & 0.09 & 0.08 & 0.05 & 0.04 & 1.00 \\
\hline Branching Reds & 0.05 & 0.11 & 0.04 & 0.11 & 0.12 & 0.21 & 0.23 & 0.04 & *0.33 \\
\hline Laurencia & 0.13 & 0.08 & 0.03 & 0.14 & 0.13 & 0.06 & 0.14 & 0.17 & 0.28 \\
\hline Microdictyon & 0.06 & 0.06 & 0.20 & $* 0.36$ & $* 0.33$ & 0.08 & $* 0.32$ & 0.08 & 0.16 \\
\hline Cladophorpsis & $* * * 0.47$ & $* 0.30$ & 0.20 & 0.21 & 0.11 & $* 0.34$ & 0.01 & 0.13 & 0.15 \\
\hline Calcareous Greens & 0.11 & 0.17 & 0.06 & 0.11 & 0.23 & 0.06 & 0.13 & 0.08 & 0.27 \\
\hline Cyanobacteria & 0.11 & 0.26 & $* 0.34$ & 0.25 & 0.22 & 0.03 & 0.11 & 0.16 & 0.03 \\
\hline Bleaching & $* * 0.41$ & 0.11 & 0.22 & $* * * 0.50$ & 0.07 & 0.14 & 0.13 & 0.01 & 0.25 \\
\hline White Plague & $* * 0.46$ & 0.19 & 0.07 & **0.38 & 0.10 & 0.14 & 0.13 & 0.19 & *0.34 \\
\hline Black Band & $* 0.29$ & 0.08 & 0.20 & 0.17 & 0.16 & 0.01 & 0.20 & 0.12 & 0.04 \\
\hline Gorgonian Disease & 0.20 & 0.13 & $* 0.32$ & 0.15 & 0.02 & 0.23 & 0.11 & 0.06 & 0.05 \\
\hline Exposure & 0.05 & 0.17 & 0.07 & $* 0.30$ & 0.12 & 0.18 & 0.26 & 0.19 & 0.19 \\
\hline Depth & $* * * 0.69$ & $* 0.34$ & $* 0.35$ & $* * 0.46$ & 0.10 & 0.16 & 0.03 & 0.23 & *0.31 \\
\hline Development & 0.22 & 0.07 & $* 0.33$ & 0.11 & $* 0.32$ & 0.06 & 0.13 & $* 0.31$ & 0.11 \\
\hline Turbidity & 0.10 & 0.09 & 0.25 & 0.11 & $* * 0.39$ & 0.16 & 0.15 & 0.13 & 0.02 \\
\hline Green Water & $* * 0.40$ & $* * 0.44$ & 0.16 & $* * 0.39$ & 0.10 & 0.28 & 0.14 & 0.09 & 0.17 \\
\hline Point Source & 0.09 & **0.38 & 0.19 & 0.09 & 0.28 & 0.03 & 0.20 & 0.00 & 0.25 \\
\hline Seepage & 0.13 & $* * * 0.48$ & 0.28 & 0.22 & $* 0.36$ & 0.02 & 0.03 & 0.25 & 0.21 \\
\hline
\end{tabular}


TABLE 2 (Continued)

Matrix of Spearman rank order correlation coefficients between all pairs of variables. The triangular lower left half of the matrix gives the numerical value of the correlation coefficient. Numbers unmarked are not statistically significant $(P>0.05)$, numbers marked by * are statistically significant at the $P<0.05$ level, numbers marked by ** are strongly statistically significant at the $P<0.01$ level, and numbers marked by $* * *$ are very strongly statistically significant at the $P<0.001$ level. The triangular upper right half of the matrix gives the sign of the correlation. Abbreviations given in text.

\begin{tabular}{|c|c|c|c|c|c|c|c|c|c|}
\hline & $\begin{array}{c}\text { Branch } \\
\text { Reds }\end{array}$ & Laurencia & Microdictyon & Cladophorpsis & $\begin{array}{l}\text { Calc. } \\
\text { Green }\end{array}$ & $\begin{array}{c}\text { Cyan. } \\
\text { Bacteria }\end{array}$ & Bleaching & White Plague & $\begin{array}{l}\text { Black } \\
\text { Band }\end{array}$ \\
\hline Coral Cover & + & - & - & - & + & - & + & + & + \\
\hline Bare Cover & - & - & - & - & + & - & + & + & + \\
\hline Padina & - & - & + & + & - & - & - & - & - \\
\hline Lobophora & + & + & + & - & - & + & + & + & + \\
\hline Stypopodium & + & + & + & - & - & - & + & + & + \\
\hline Sargassum & + & - & + & + & - & + & - & - & + \\
\hline Turbinaria & + & - & + & + & - & + & + & + & + \\
\hline Dictyota & + & - & + & - & + & - & + & + & + \\
\hline Crustose Reds & + & - & - & - & + & - & + & + & + \\
\hline Branching Reds & 1.00 & - & + & - & - & - & + & + & + \\
\hline Laurencia & 0.01 & 1.00 & - & - & + & - & + & + & + \\
\hline Microdictyon & 0.18 & 0.19 & 1.00 & - & - & - & + & + & + \\
\hline Cladophorpsis & 0.06 & 0.02 & $* 0.29$ & 1.00 & + & + & - & - & - \\
\hline Calcareous Greens & 0.03 & 0.05 & $* * 0.45$ & 0.25 & 1.00 & + & - & + & - \\
\hline Cyanobacteria & 0.04 & 0.10 & 0.03 & 0.13 & 0.17 & 1.00 & - & - & - \\
\hline Bleaching & 0.19 & 0.06 & 0.21 & 0.21 & 0.14 & 0.02 & 1.00 & + & + \\
\hline White Plague & 0.14 & 0.01 & 0.17 & $* * 0.45$ & 0.07 & 0.22 & $* * * 0.56$ & 1.00 & + \\
\hline Black Band & *0.30 & 0.06 & 0.19 & $* 0.30$ & 0.08 & $* 0.37$ & $* 0.36$ & $* * * 0.58$ & 1.00 \\
\hline Gorgonian Disease & 0.25 & $* 0.29$ & 0.16 & 0.15 & 0.12 & 0.13 & 0.23 & $* * 0.42$ & 0.07 \\
\hline Exposure & 0.13 & 0.10 & $* 0.32$ & 0.20 & 0.28 & 0.01 & $* 0.32$ & 0.06 & 0.05 \\
\hline Depth & 0.10 & 0.18 & 0.14 & $* * 0.43$ & 0.11 & 0.08 & $* * * 0.59$ & $* * * 0.49$ & 0.18 \\
\hline Development & 0.00 & 0.28 & 0.07 & 0.01 & 0.06 & 0.04 & 0.02 & 0.08 & 0.02 \\
\hline Turbidity & 0.07 & $* 0.33$ & 0.05 & 0.12 & 0.07 & 0.05 & 0.07 & 0.05 & 0.07 \\
\hline Green Water & 0.14 & 0.23 & 0.11 & 0.24 & 0.23 & 0.08 & 0.10 & 0.06 & 0.02 \\
\hline Point Source & 0.07 & 0.21 & 0.11 & 0.09 & 0.16 & 0.03 & 0.27 & 0.08 & 0.01 \\
\hline Seepage & 0.01 & 0.12 & 0.07 & 0.15 & 0.02 & 0.04 & 0.04 & 0.10 & 0.06 \\
\hline $\begin{array}{l}*=\mathrm{p}<0.05 \\
* *=\mathrm{p}<0.01 \\
* * *=\mathrm{p}<0.001\end{array}$ & & & & & & & & & \\
\hline
\end{tabular}


TABLE 2 (Continued)

Matrix of Spearman rank order correlation coefficients between all pairs of variables. The triangular lower left half of the matrix gives the numerical value of the correlation coefficient. Numbers unmarked are not statistically significant $(P>0.05)$, numbers marked by * are statistically significant at the $P<0.05$ level, numbers marked by ** are strongly statistically significant at the $P<0.01$ level, and numbers marked by $* * *$ are very strongly statistically significant at the $P<0.001$ level. The triangular upper right half of the matrix gives the sign of the correlation. Abbreviations given in text.

\begin{tabular}{|c|c|c|c|c|c|c|c|c|}
\hline & $\begin{array}{c}\text { Gorgo } \\
\text { Dis. }\end{array}$ & Exposure & Depth & Development & Turbidity & $\begin{array}{l}\text { Green } \\
\text { Water }\end{array}$ & Point Source & Seepage \\
\hline Coral Cover & + & - & + & + & + & - & - & - \\
\hline Bare Cover & + & + & + & - & + & - & - & - \\
\hline Padina & - & - & - & + & + & + & + & + \\
\hline Lobophora & + & + & + & - & - & + & - & - \\
\hline Stypopodium & - & + & + & - & - & - & - & - \\
\hline Sargassum & - & + & - & - & + & + & - & + \\
\hline Turbinaria & - & + & - & - & + & + & - & + \\
\hline Dictyota & - & - & + & + & + & - & - & + \\
\hline Crustose Reds & - & + & + & - & - & - & - & - \\
\hline Branching Reds & - & + & + & + & - & + & + & - \\
\hline Laurencia & + & - & - & - & - & + & - & - \\
\hline Microdictyon & - & + & + & + & - & + & + & - \\
\hline Cladophorpsis & - & - & - & - & + & + & + & + \\
\hline Calcareous Greens & + & - & - & - & - & - & - & - \\
\hline Cyanobacteria & + & - & + & - & - & + & - & + \\
\hline Bleaching & + & + & + & - & - & + & - & - \\
\hline White Plague & + & + & + & + & + & + & - & - \\
\hline Black Band & + & + & + & + & + & + & + & + \\
\hline Gorgonian Disease & 1.00 & - & + & - & + & - & - & - \\
\hline Exposure & 0.19 & 1.00 & + & - & - & + & - & - \\
\hline Depth & 0.23 & 0.19 & 1.00 & + & - & - & - & - \\
\hline Development & 0.05 & $* 0.31$ & 0.09 & 1.00 & + & - & + & + \\
\hline Turbidity & 0.10 & 0.16 & 0.06 & $* * * 0.59$ & 1.00 & + & + & + \\
\hline Green Water & 0.04 & 0.10 & 0.14 & 0.01 & 0.08 & 1.00 & + & + \\
\hline Point Source & $* 0.33$ & 0.08 & 0.17 & $* * 0.45$ & 0.14 & $* 0.34$ & 1.00 & + \\
\hline Seepage & 0.23 & 0.24 & *0.32 & $* * * 0.51$ & $* 0.30$ & 0.20 & 0.41 & 1.00 \\
\hline
\end{tabular}


TABLE 3

Summary of the frequency of positive and negative correlations by their degree of statistical significance

DEGREE OF SIGNIFICANCE

Very strongly significant

Strongly significant

Significant

Not Significant

been given short shrift, or ignored, in most reef assessment, which in effect amounts to throwing out the richest and most diagnostic set of data. Furthermore the data reveals a wealth of both positive and negative interactions between many algae species. These presumably result from competitive, parasitic, commensal, or exclusionary allellopathic interactions that have not been described. Much further research is warranted to test the hypotheses generated in this paper and ascribe sound mechanisms that could explain them. In addition the data reveals those algae species whose abundances are negatively correlated with coral abundance, indicating that these are the most effective at overgrowing and killing corals.

Upewlling: The role of upwelling in promoting high nutrient backgrounds and algal dominance in areas remote from human nutrient impacts or of fishing strongly supports the primary role of nutrients in controlling algae productivity, and indicates that many areas that are "pristine" in the sense of having little human impact may not have healthy coral reefs. Therefore more stringent controls on land-based nutrient sources are needed wherever there are high backgrounds. The areas of upwelling appear to be systematic and are interspersed with areas of lower algae and blue water,. Much work needs to be done on hydrodynamic-topographic controls over upwelling to identify the areas affected.
POSITIVE

NEGATIVE

$\begin{array}{cc}10 & 2 \\ 11 & 7 \\ 20 & 14 \\ 130 & 131\end{array}$

\section{Our conclusions are:}

1. Live coral cover is declining: Dead coral exceeded live coral at all sites, often by very large amounts. The best reefs had about $40 \%$ live coral cover, but even there dead coral was more abundant than live coral and some of these sites had been observed to have up to $70 \%$ live coral cover 11 years before (Goreau 1995). Large areas of shallow reef framework seem to have died from White Band Disease around 1979, and have shown little signs of recovery since. Progressive mortality appears to be underway from episodes of coral bleaching, coral diseases, algae overgrowth, and in some locations near dredging, from excessive turbidity. The result is a continuing decline in biodiversity, shore protection, fisheries habitat, and ecotourism environmental services. Even though many sites still have better coral cover than most Caribbean reefs, this is no cause for complacency because progressive decline is visible everywhere.

2. Most TCI reefs are algae dominated: Healthy growing coral reefs are dominated by corals, and algae-dominated reefs are unable to keep up with erosion and sea level rise. An algae-dominated reef should be called precisely that, and not confused with a healthy coral reef, because it cannot serve the same shore protection, biodiversity, or fisheries habitat roles. Because most current coral reef researchers have never seen healthy reefs, there is now 
a common practice of describing reefs as "healthy" even when they have very little live coral. For example Vroom et al. (2006) examined Pacific reefs with very low coral and very high algae cover that were regarded as being very healthy coral reefs on grounds of their remoteness from human activity. However most of their sites had very green water, as is made clear by their photographs, $91 \%$ of which show water as green as the greenest found in TCI. Deep Pacific waters have around twice the nitrate and phosphate concentration of deep Atlantic waters, and so shallow reef areas in the Pacific are even more vulnerable to high nutrient loading, especially in areas with very shallow thermoclines subject to wind-driven upwelling. Much of the current reef literature suggests that algae-dominated conditions are simply "an alternative stable state" or "phase shift", from which "resilient" coral reefs will bounce back by themselves, and algae dominated conditions are often blamed on fishermen, who are claimed to have eaten all the algae eating fish, or on sea urchin diseases. None of these "explanations" fit the situation in TCI. TCI has some of the least overfishing in the Caribbean, and the algae domination has little or no relationship to protection from fishing or absence of herbivorous fish. The high algae abundance preceded the epidemic die off of Diadema antillarum sea urchins in 1983 according to the oldest divers. Diadema was found to be abundant at some sites, and all of these had high algae cover, so they were clearly not controlling the algae and could not explain low algae cover at sites with no Diadema. The only plausible explanation for the high abundance of algae at most sites in TCI is an excess of nutrients. There is no evidence of algaedominated reefs reverting to coral dominated reefs except for those few cases where all landbased sources of nutrients have been eliminated (Goreau 2003). This is possible only where land-based sources of nutrients dominate, but not in places where upwelling is the major source. Ocean fertilization, as (incorrectly) proposed by some as a carbon sink, would make the reef algae problem worse.
3. There is a very high incidence of coral disease: Severe, but patchy, epidemic outbreaks of infectious coral diseases are underway, with White Plague, Black Band (apparently combined with White Plague), and Gorgonian Disease being the major ones in TCI at this time. These diseases typically spread faster during warm seasons, and may have been in the early stages when examined. The survey data gave a clear indication that many of these diseases are correlated with the abundance of certain algae species, lending strong circumstantial support to suggestions that some algae may serve as a reservoir for coral pathogens (Nugues et al. 2004; Smith et al. 2006). Many sites with high disease had not had them when previously surveyed by DECR personnel. In contrast, Riegl et al. (2003) found low diseases at most sites in 1999, with a maximum of $13 \%$ at two sites on South Caicos, no difference between shallow and deep areas, exposed and sheltered areas, and very low disease in Grand Turk. Most disease they saw was White Plague, very little Black Band, and they reported negligible gorgonian disease. They also found low amounts of recent coral mortality. The rapid recent spread of coral diseases is a matter of great concern, and it will be important to understand the factors involved for there to be any hope of minimizing their impacts.

\section{Coral bleaching is a major near term} threat: There have been several serious coral bleaching episodes in TCI, and partial bleaching and partial mortality from recent and past bleaching episodes were clearly visible. Bleaching has become a chronic, nearly annual, event in the last 10 years. Only very small further rises in sea surface temperature or one unusually hot year could cause serious coral mortality any year now.

\section{There is a high natural nutrient back-} ground: While brief episodes of green water conditions have long been known to divers, there is clear evidence from fishermen that many sites in TCI have chronic green water conditions, and the distribution of algae 
suggests that there are sites that have consistent upwelling, and others where it is always much rare. Upwelling not only causes green water conditions, it is a source of high nutrients from deep cold water that cause chronic blooms of benthic algae, preventing coral settlement or recovery from coral disease epidemics. The observations strongly suggest that many, possibly most, TCI shelf edge reefs suffer from chronic high nutrient backgrounds, and that due to local circulation patterns, these upwelling events are much more frequent at some sites than others. This means that there are probably not many high quality unutilized dive sites that could be used if the current tourist dive sites are damaged from overuse.

\section{It is crucial to control land based} sources of nutrients: Land-based sources of nutrients have clearly caused a spread of algae over many shallow reefs used for snorkeling and fishing near populated areas. Several shallow inshore areas in Grand Turk that were previously dominated by clean white limestone rock (Goreau 1995), were algae covered in 2006. Because of the high natural nutrient background caused by upwelling, TCI waters are highly vulnerable to eutrophication (nutrient-caused proliferation of weedy algae), and only very small increases in land-based sources of nutrients can trigger massive algae overgrowth of entire reefs (Goreau 1992, Goreau and Thacker 1994, Lapointe et al. 1994, 2004, Lapointe 1997, Goreau 2003). TCI cannot afford to be complacent that it is less vulnerable to eutrophication than other Caribbean islands, such as Jamaica, that have much higher populations, rainfall, and hydraulic gradients. In those islands, the thermocline is much deeper, and natural offshore backgrounds of nutrients are lower than in TCI, which sits in an area of shallow thermoclines and higher deep Atlantic nutrient levels. Control of land-based sources of nutrients is even more crucial in TCI because off the higher natural background nutrient levels.
8. Damage to shallow reefs and sea level rise pose major medium term erosion risks: The dead elkhorn reef frameworks that protected much of the TCI coastline prior to 1979 is slowly being broken apart by hurricanes and bio-eroding sponges, clams, worms, algae, and fungi, and new settlement and growth is far too low to replace them. While at the moment beach erosion is confined to a few relatively limited sites, global sea level rise, now $3 \mathrm{~mm}$ a year, but due to rise rapidly in coming decades, coupled with increasing hurricane strength and frequency, is medium term threat to TCI beaches that requires a pro-active strategy to protect the beaches and low lying developed areas.

9. Coral reef restoration is important for long term sustainability of tourism, fisheries, and shore protection: Long term maintenance of the ecosystem services that only healthy coral reefs can provide, in the face of accelerating threats to corals from local, regional, and global stresses, means that relying on the reefs to come back by themselves, as they did after past hurricanes and shipwrecks, will no longer work. Future management will require active strategies to restore critical reef areas by reducing stresses to reefs and actively growing corals using methods that increase their growth rate, their resistance to environmental stress, and their quality for fish and shellfish habitat (Goreau \& Hilbertz, 2005).

Policy recommendations for TCI based on these conclusions are presented in the online supplements.

\section{ACKNOWLEDGMENTS}

We thank the entire staff of DECR for assistance with office and field work and logistics that made this study possible. We thank the dive operators for discussion on long-term change in TCI reefs, especially Art Pickering, Algrove Alexander Smith, Mitch Rollins, Everette Freites, and Michael Clarke. In particular we thank Wesley Clervaux, Brian 
Riggs, and the boat captains and staff. We thank the entire Reef Check TCI Team for independently cross checking the accuracy of the visual bottom cover estimates.

\section{RESUMEN}

La salud de los arrecifes coralinos de las Islas Turcas y Caicos (uno de los mejores sistemas arrecifales en la región) es vital para su bienestar económico y ambiental. Los métodos tradicionales de evaluación proporcionan relativamente poca información porque cubren un área muy pequeña para caracterizar con precisión complejos sistemas arrecifales, no pueden captar integralmente pautas a gran escala y además la alta variabilidad espacial intrínseca de los arrecifes inhibe la capacidad de los datos obtenidos en pequeñas áreas para identificar cambios o causas. Las investigaciones espacialmente extensivas suministran más información, sobre áreas mayores y en menos tiempo que las intensivas, revelando gradientes a gran escala que los métodos intensivos son inherentemente incapaces de identificar y brindan un nuevo paradigma que pudiera usarse ampliamente para el manejo ambiental, con mayor efectividad económica. A principios de junio de 2006 se llevaron a cabo investigaciones extensivas, evaluándose 26 parámetros ecológicos y ambientales en 47 sitios arrecifales a lo largo de las Islas. Se puso especial énfasis en identificar las diferentes zonas de algas a lo largo de gradientes ambientales. Los datos obtenidos están siendo utilizados para desarrollar estrategias nacionales de manejo de la calidad de agua y de restauración de corales.

Palabras clave: Evaluación ecológica de arrecifes coralinos a gran escala, análisis de gradientes ambientales, manejo de zonas costeras, zonas de algas, sistemas de comunidades coralinas, enfermedades, blanqueamiento.

\section{REFERENCES}

Bruno, J. F., L. E. Petes, C. D. Harvell \& A. Hettinger. 2003. Nutrient enrichment can increase the severity of coral diseases. Ecol. Lett. 6: 1056-1061.

Campbell, J. L., T. Fisher, \& F. Perez. 2006. A Management Plan for the Columbus Landfall National Park and Other Protected Areas in and Around Grand Turk. Department of Environment and Coastal Resources. Ministry of Natural Resources. Turks and Caicos Islands. Executive Council Minute No. 06/36, Paper 06/274. 99 p.

Environmental Charter agreed between the Turks and Caicos Islands and the United Kingdom. 2002. Plan for Biodiversity Management and Sustainable Development around the Turks and Caicos RAMSAR Site. p. 166-167.
Fisher, T. 2004. Assessment of reefs at dive sites in Providenciales, Grand Turk, and South Caicos. Department of Environment and Coastal Resources. Ministry of Natural Resources. Turks and Caicos Islands. 27 p.

Gascoine, B., \& C. Lott. 1991. Diving, Snorkeling, Visitor’s Guide to the Turks and Caicos Islands. Graphics Reproductions. Lake Park, Florida, USA. 94 p.

Gaudian, G. \& P. A. H. Medley. 1995. Diver carrying capacity and reef management in the Turks and Caicos Islands. Bahamas J. Sci. 3: 9-14.

Gaudian, G. \& P. A. H. Medley. 2000. Turks and Caicos Islands. Pp. 587-594. In C. R. C. Sheppard (editor), Seas at the Millenium: An Environmental Evaluation, Elsevier.

Gladfelter, W. B. 1982. White-Band Disease in Acropora Palmata: Implications for the structure and growth of shallow reefs. Bull. Mar. Sci. 32: 639-643.

Goreau, T. F. 1956. A Study of the Biology and Histochemistry of Corals. Yale University, New Haven, Connetticut, USA. 277 p.

Goreau, T. F., J. C. Lang, E. A. Graham \& P. D. Goreau. 1972. Structure and ecology of the Saipan reefs in relation to predation by Acanthaster planci (Linnaeus). Bull. Mar. Sci. 22:113-152.

Goreau, T. F. \& N. I. Goreau. 1973. The ecology of Jamaican coral reefs. II. Geomorphology, zonation, and sedimentary phases. Bull. Mar. Sci. 23:399-464.

Goreau, T. J. 1992. Bleaching and reef community change in Jamaica: 1951-1991. Amer. Zool. 32: 683-695.

Goreau, T. J. 1995. Artificial reef development in the Turks and Caicos: Environmental assessment and proposed projects. Annex to Turks and Caicos Islands: Coral reef assessment, and restoration and management strategy. 2006. Department of Environment and Coastal Resources. Ministry of Natural Resources. Turks and Caicos Islands. 17 p.

Goreau, T. J. 2003. Waste Nutrients: Impacts on coastal coral reefs and fisheries, and abatement via land recycling. United Nations Expert Meeting On Waste Management In Small Island Developing States. Havana, Cuba. 28 p.

Goreau, T. J. \& R. L. Hayes. 1995. A survey of coral reef bleaching in the South Central Pacific during 1994: Report to the International Coral Reef Initiative. Global Coral Reef Alliance, Chappaqua, New York, USA. 201 p. 
Goreau, T. J., J. Cervino, M. Goreau, R. Hayes, M. Hayes, L. Richardson, G. Smith, K. DeMeyer, I. Nagelkerken, J. Garzon-Ferrera, D. Gil, G. Garrison, E. H. Williams, L. Bunkley-Williams, C. Quirolo, K. Patterson, J. Porter \& K. Porter. 1998. Rapid spread of diseases in Caribbean coral reefs. Rev. Biol. Trop. 46 (Suppl. 5): 157-171.

Goreau, T. J. \& W. Hilbertz. 2005. Marine ecosystem restoration: costs and benefits for coral reefs. World Res. Rev. 17: 375-409.

Goreau, T. J. \& K. Thacker. 1994. Coral Reefs, sewage, and water quality standards. Proc. Carib. Water Wastewater Asso. 3: 98-116.

Harrigan, S. 1992. Water and Light: A Diver's Journey to a Coral Reef. Houghton Mifflin, Boston, Massachussetts, USA. 277 p.

Hayes, R. L. \& T. J. Goreau. 2008. An analysis of satellitederived sea surface temperature from Caribbean and Atlantic coral reef sites, 1982-2003. Rev. Biol. Trop. 56 (Suppl.). 197-218.

Homer F. \& D. Shim. 2000. Status of coral reefs in the Turks and Caicos Islands, An overview for the Global Coral Reef Monitoring Network. p. 1-6.

Hoshino, K., M. Brandt, C. Manfrino, B. Riegl \& S. Steiner. 2003. Assessment of the coral reefs of the Turks and Caicos Islands (Part 2: Fish communities). In J. Lang (editor), Status of reefs in the Western Atlantic: Results of the initial surveys, Atlantic and Gulf Rapid Reef Assessment (AGRRA) Program. Atoll Res. Bull. 496: 480-499.

Kaczmarsky, L. T., M. Draud \& E. H. Williams. 2005. Is there a relationship between proximity to sewage effluent and the prevalence of coral disease? Carib. J. Sci. 41: 124-132.

Klaus, J. S., I. Janse, J. M. Heikoop, E. A. Sanford \& B. W. Fouke. 2007. Coral microbial communities, zooxanthellae, and mucus along gradients of water depth and coastal pollution. Environm. Microbiol. 9: 1291-1305.

Kuntz, N. M., D. I. Kline, S. A. Sandin \& F. Rohwer. 2005. Pathologies and mortality rates caused by organic carbon and nutrient stressors in three Caribbean coral species. Mar. Ecol. Prog. Ser. 294: 173-180.

Lapointe, B. E. 1997. Nutrient thresholds for bottomup control of macroalgal blooms on coral reefs in Jamaica and Southeast Florida. Limnol. \& Oceanogr. 42: 1119-1131.
Lapointe, B. E., D. A. Tomasko \& W. R. Matzie. 1994. Eutrophication and trophic state classification of seagrass communities in the Florida Keys. Bull. Mar. Sci. 54: 696-717

Lapointe, B. E., P. J. Barile, C. S. Yentsch, M. M. Littler, D. S. Littler \& B. Kakuk. 2004. The relative importance of nutrient enrichment and herbivory on macroalgal communities near Norman's Pond Cay, Exumas Cays, Bahamas: a "natural” enrichment experiment. J. Exp. Mar. Biol. Ecol. 298: 275-301.

Littler, D. S. \& M. M. Littler. 2000. Caribbean Reef Plants. OffShore Graphics, Washington, D.C. 542 p.

Nugues, M. M. 2002. Impact of a coral disease outbreak on coral communities in St. Lucia: What and how much has been lost. Mar. Ecol. Prog. Ser. 229: 61-71.

Nugues, M. M., G. W. Smith, R. J. Van Hooidonk, M. I. Seabra \& R. P. M. Bak. 2004. Algal contact as a trigger for coral disease. Ecol. Lett. 7: 919-923.

Perez, F. 2000. Rapid assessment of impacts on the coastal environment with particular emphasis on protected areas in Providenciales. Phase 1. Impacts on the coastal environment with particular emphasis on protected areas in Providenciales, Second Phase. Coastal Resources Management Project. Ministry of Natural Resources. Providenciales. Turks and Caicos Islands. 77 p.

Riegl, B., C. Manfrino, C. Hermoyian, M. Brandt \& K. Hoshino. 2003. Assessment of the coral reefs of the Turks and Caicos Islands (part 1: stony corals and algae). In J. Lang (editor), Status of reefs in the Western Atlantic: Results of the initial surveys, Atlantic and Gulf Rapid Reef Assessment (AGRRA) Program. Atoll Res. Bull. 496: 460-479.

Rosenberg, S. 2001. Diving and Snorkeling Turks and Caicos. Lonely Planet, Melbourne, Australia. 127 p.

Rudd, M. A. 2003. Fisheries landings and trade of the Turks and Caicos Islands. Fisheries Centre Research Reports 11: 149-161.

Sadler, H. E. 1997. Turks Islands Landfall: A History of the Turks and Caicos Islands. United Cooperative Printers, Kingston, Jamaica. 299 p.

Sear, C., M. Hulme, N. Adger \& K. Brown. 2001. The impacts of global climate change on the UK Overseas Territories. National Resource Institute, The Tyndall Centre, London, England. 51 p. 
Smith, J. E., M. Shaw, R. A. Edwards, D. Obura, A. Pantos, E. Sala, S. A. Sandin, S. Smriga, M. Hatay \& F. M. Rohwer. 2006. Indirect effects of algae on coral: algae-mediated, microbe-induced coral mortality. Ecol. Lett. 9: 835-845

Steiner, S. C. C. 1999. Species presence and distribution of Scleractinia (Cnidaria: Anthozoa) from South Caicos, Turks and Caicos Islands. Bull. Mar. Sci. 65: 861-871

Sullivan, K., M. Chiappone \& C. Lott. 1994. Abundance patterns of stony corals on platform margin reefs of the Caicos Bank. Bahamas J. Sci. 1: 2-12
Topalian, T. 1992. An assessment of the status and needs of marine conservation, education, policy and resource management in Turks and Caicos Islands, British West Indies. Proc. $7^{\text {th }}$ Int. Coral Reef Symp., Guam 2: 1083-1090.

Vroom, P., K. N. Page, J. C. Kenyon \& R. E. Brainard. 2006. Algae-dominated reefs. Amer. Scient. 94: 430-437. 
